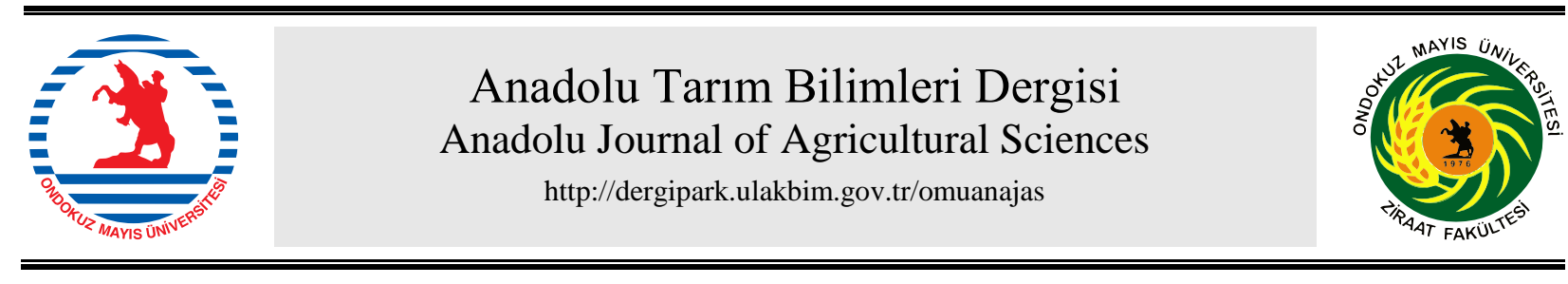

Research/Araşturma

Anadolu Tarım Bilim. Derg./Anadolu J Agr Sci, 32 (2017) ISSN: $1308-8750$ (Print) 1308-8769 (Online) doi: 10.7161/omuanajas.289604

\title{
Determination of energy balance of apple (Malus domestica) production in Turkey: A case study for Tekirdag province
}

\author{
İlker H. Çelen ${ }^{\mathrm{a} *}$, Mehmet Fırat Baran ${ }^{\mathrm{b}}$, Eray Önler ${ }^{\mathrm{a}}$, Yılmaz Bayhan ${ }^{\mathrm{a}}$ \\ ${ }^{a}$ University of Namik Kemal, Faculty of Agriculture, Department of Biosystems Engineering, 59100 Tekirdağ, Turkey \\ ${ }^{b}$ University of Adlyaman, Faculty of Technology, Department of Energy Systems Engineering, 02040/ Adlyaman, Turkey \\ *Corresponding author/sorumlu yazar: icelen@nku.edu.tr
}

Received/Geliş 15/04/2016 Accepted/Kabul 03/08/2016

\begin{abstract}
This study aims to define the energy usage efficiency in apple cultivation in the Province of Tekirdağ. The study was conducted during 2015 production season through observation and measurement in an apple garden with a land area of $12 \mathrm{da}$ and located in Nusratlı village in Central Tekirdağ. It has been tried to reveal the role of mechanization energy among all the inputs. According to the calculated data, in apple cultivation the respective figures for total energy input, total fruition, total energy output, energy output/input rate, specific energy, energy productivity and net energy have been calculated as 58839.65 MJ ha-1, 38370 kg ha-1, 92088.00 MJ ha-1, 1.56, 1.53 MJ kg-1, 0.65 kg MJ-1 and 33248.35 MJ ha-1 respectively. As a result, among the general energy inputs in apple cultivation, the highest energy consuming items have been respectively defined as fertilizer energy, fuel-oil energy, chemicals, machinery, human labour and irrigation energy.
\end{abstract}

Elma (Malus communis L) yetiştiriciliğinde enerji girdi-çıktı analizi: Tekirdağ ili örneği

\section{ÖZET}

$\mathrm{Bu}$ çalışmada, Tekirdağ ilinde yetiştirilen elma yetiştiriciliğinde enerji kullanım etkinliğinin belirlenmesi amaçlanmıştır. Enerji kullanım etkinliği çalışması, Tekirdağ ili Merkez ilçesi Nusratlı köyündeki bir işletmede 2015 üretim sezonunda 12 da alana sahip elma bahçesinde yapılan gözlem ve ölçüm yoluyla gerçekleştirilmiştir. Girdiler içerisinde mekanizasyon enerjisinin rolü ortaya konulmaya çalışılmıştır. Hesaplanan verilere göre, elma yetiştiriciliğinde toplam enerji girdisi, toplam ürün verimi, toplam enerji çıktısı, enerji çıktı/girdi oranı, özgül enerji, enerji verimliliği ve net enerji verimi sırasıyla 58839.65 MJ ha-1, $38370 \mathrm{~kg}$ ha-1, 92088.00 MJ ha-1, 1.56, 1.53 MJ kg-1, 0.64 kg MJ-1 ve 33248.35 MJ ha-1 olarak belirlenmiştir. Sonuç olarak, elma yetiştiriciliğinde genel enerji girdileri içerisinde en fazla enerji tüketim sırasıyla gübre enerjisi, yakıt-yağ enerjisi, kimyasallar, makine, insan işgücü ve sulama enerjisi olarak belirlenmiştir.

\author{
Keywords: \\ Inpu energy \\ Output energy \\ Apple \\ Energy use efficiency \\ Tekirdağ
}

\section{Introduction}

With an approximate production level of 2.5 million tons, Turkey is ranked 4th in world apple production, preceded by China, USA and France. However, Turkey's apple exportation level is significantly low, with an annual figure of 25-30 thousand tons. In order to increase the level of apple exportation, we need to cultivate the varieties demanded by foreign markets as per standards (Anonymous, 2016a).

Apple is a variety which exhibits vast sprawl in the world and it can be planted in highly different ecologies.
The native land of apple is South Caucasus encompassing Anatolia. Due to suitable ecologic conditions and hosting the gene centre, apple has been cultivated in almost every corner of Turkey for many long years. But the most suitable centres of culturing are located in Northern Anatolia, in line with the spreading areas of crab-apple. Northern Anatolia, coastal line of the Black Sea, the straits between the Central Anatolian and Eastern Anatolian arcs and recently, the region of lakes in the south constitute the outstanding cultivation areas of apple (Cennet and Karaçayır, 2009).

Fruit cultivation takes place in approximately $14 \%$ 
of the total agricultural land in Turkey. A member of pome fruit group, apple makes up $5.3 \%$ of total fruit areas and $0.7 \%$ of total agricultural areas (Anonymous, 2016b). Apple has an important nutritional value due to the minerals and vitamins it contains. Fresh apple fruit consists $84 \%$ of water. Carbohydrates, proteins, vitamins, pectin and mineral matters are found inside the dry matter. Vitamins A and C, as well as elements such as potassium, calcium, magnesium and sodium found in apple merge to form certain types of salt. When the organic parts of these salts, in other words organic acids, oxide in blood to generate energy, residues are left behind which form base. Hence, apple has a positive effect on the blood's acid-base balance. As such, a research in England has revealed that a single apple a day significantly reduces the risk of cancer (Cennet and Karaçayır, 2009).

In order to increase energy efficiency value, either productivity needs to be increased or the inputs need to be reduced. In particular, fuel, chemical fertilizers, agricultural pesticides, machine and tractor inputs, which take up an important share among total energy input, need to be reduced. Productivity increase can be realized within certain restrictions. However, energy usage efficiency value can be reduced by wiser use of inputs (chemicals, mechanisation and fertilizing) (Gözübüyük et al., 2009). In order to increase production, producers are employing inputs with higher energy, without having any knowledge about inputs with more efficient energy input. This leads to inflated production costs. For sustainability of production, production inputs need to be determined to allow for energy analysis. Use of energy analysis would provide a methodology for energy flow within the agricultural production system (Pimentel, 1980). Many researches related to energy output/input analyses have been conducted with the aim of determining energy efficiency in agricultural production.

Modern fruit cultivation methods have become a obligation in recent years due to economic conditions and changing market demands. In fruit cultivation it is a principle to yield higher quantity and higher quality products per unit area. Apple cultivation in Turkey yields an average of $1.335 \mathrm{~kg}$ per decare, but the average yield in developed countries is 6-8 tons per decare. This is due to the fact that those countries are employing modern cultivation methods, rather than traditional ones.

In a study aiming to determine the energy use efficiency of dwarf apple production in Antalya, Yilmaz et al. (2010) have calculated the total energy input as $47666 \mathrm{MJ} \mathrm{ha}^{-1}$, total energy output $107650 \mathrm{MJ} \mathrm{ha}^{-1}$, and energy use efficiency as 2.26 .

In a study related to modelling energy inputs and sensitivity analysis of apple production in Tehran, Rafiee et al. (2010) have calculated the total energy input as $42819.25 \mathrm{MJ} \mathrm{ha}^{-1}$. The highest input among energy inputs has been observed in fuel energy by 21.22 $\%$, which was followed by fertilizer energy by $17.66 \%$.
Ekinci et al. (2005) performed a survey on 109 apple producers located in 14 villages in Isparta and based on their findings, total energy input value was 42252.82 $\mathrm{MJ} \mathrm{ha}^{-1}$, total energy output value was $69073.17 \quad$ MJ $\mathrm{ha}^{-1}$, and the figure for energy use efficiency was 1.63. According to the results, $16.45 \%$ of the total energy input was formed by renewable energy resources, while $83.55 \%$ was formed by non-renewable energy resources.

In a study dealing with energy in melon and watermelon cultivation in dry agriculture conditions in Kırklareli, the gathered results by Baran and Gokdogan (2014) indicated total energy input, total productivity, total energy output, energy output/input rate, specific energy, energy efficiency and net energy figures of $11219.66 \mathrm{MJ} \mathrm{ha}^{-1}, 28000 \mathrm{~kg} \mathrm{ha}^{-1}, 53200 \mathrm{MJ} \mathrm{ha}^{-1}, 4.74$, $0.40 \mathrm{MJ} \mathrm{kg}^{-1}, 2.49 \mathrm{~kg} \mathrm{MJ}^{-1}$ and $41980.34 \mathrm{MJ} \mathrm{ha}^{-1}$ respectively for water-melon cultivation; and total energy input, total productivity, total energy output, energy output/input rate, specific energy, energy efficiency and net energy figures of $11644.47 \mathrm{MJ} \mathrm{ha}^{-1}$, $18250 \mathrm{~kg} \mathrm{ha}^{-1}, 34675 \mathrm{MJ} \mathrm{ha}^{-1}, 2.97,0.63 \mathrm{MJ} \mathrm{kg}^{-1}, 1.56$ $\mathrm{kg} \mathrm{MJ}^{-1}$ and $23030.53 \mathrm{MJ} \mathrm{ha}^{-1}$ respectively for melon cultivation.

In a study aiming to determine the energy input and outputs used for canola production in Kurklareli, Baran et al. (2014) concluded an energy output / input rate of 17.12 , specific energy value of $1.39 \mathrm{MJ} \mathrm{kg}-1$ and a net energy production of $91683.56 \mathrm{MJ}$ ha-1 for canola production. Among the total energy inputs in canola production, fuel-oil energy has been defined to be the one with highest rate of use by $52.34 \%$. It was followed by machine energy, $21.32 \%$, and fertilizer energy, $13.55 \%$.

In a study conducted by Baran et al. (2015) in a 150 decare enterprise cultivating organic pomegranate in Adiyaman; they determined the following energy inputs for organic pomegranate cultivation: $792.09 \mathrm{MJ} \mathrm{ha}^{-1}$ $(27.72 \%)$ fuel energy, $523.32 \mathrm{MJ} \mathrm{ha}^{-1}(18.31 \%)$ human labour energy, $500 \mathrm{MJ} \mathrm{ha}^{-1}(17.50 \%)$ farm fertilizers energy, $378 \mathrm{MJ}$ ha-1 (13.23 \%) irrigation water energy, $302.40 \mathrm{MJ} \mathrm{ha}^{-1}(10.58 \%)$ machinery energy, $211.20 \mathrm{MJ}$ $\mathrm{ha}^{-1}(7.39 \%)$ electric energy, $135 \mathrm{MJ} \mathrm{ha}^{-1}(4.72 \%)$ and 15.44 $\mathrm{MJ} \mathrm{ha}^{-1}(0.54)$ organic pesticide.

In this study, an energy input-output analysis has been performed during 2015 production season in a 12 da enterprise cultivating apple in Tekirdağ's Nusratl village to define the energy use efficiency.

\section{Materials and Methods}

\subsection{Material}

Tekirdağ is located in North-western Turkey and North of Marmara Sea, and is one of the three provinces having the whole land are in Thrace region, and also one of the six provinces with a coastal line in two different seas in Turkey. With a land area of $6.313 \mathrm{~km}^{2}$, the province is surrounded by Istanbul in east, Kırklareli 
in north, Edirne in west, Dardanelles in south-west and Marmara Sea in south. From the north-east, it has a 25 $\mathrm{km}$ shoreline along the Black Sea (Anonymous, 2016c).

In terms of climate conditions, Tekirdag is the most suitable area in the Thrace region, and it is suitable for apple, pear and some other fruits. For early fruit varieties, Tekirdağ offers a 10-15 days advantage compared to central regions and it also offers a closer distance to the market. Tekirdağ, based on 2014 data, has produced 5.220 tons of apples (Anonymous, 2016d).

This study has been performed during 2015 production season in a 12 da enterprise cultivating apple in Tekirdağ's Nusratlı village. The enterprise is cultivating dwarf apple (inter-trees: $3.6 \mathrm{~m} \mathrm{x} 0.8 \mathrm{~m}$; tree height $\mathrm{x}$ width: $1.80 \mathrm{~m} \mathrm{x} 1 \mathrm{~m}$ ). The trial zone is covered with "Galaxy Gala" and "Granny Smith" dwarf apple type (Malus domestica) trees.

\subsection{Method}

\subsubsection{Arranging and execution of the trial (12 da)}

The work of gathering study values in the apple garden started at the beginning of winter, before trimming. It went on through the beginning of winter. All values have been compiled in a detailed manner in Excel, indicating quantities and date.

The number and characteristics of production processes in apple production is effective on the energy balance of the performed production. Therefore, all kinds of practices and inputs related to apple cultivation in apple production have been acquired through the trial. In order to get the energy efficiency of apple production in Tekirdağ, first of all we need to calculate the energy inputs and energy outputs. Energy inputs consist of machine energy, fuel-oil energy, seed energy, fertilizer energy, disinfectant energy, water energy and human labour energy. When calculating the energy inputs and energy output, we need to know the energy equivalence of input and output types. Previous studies were used to help defining such energy equivalences. These resources have been given in Table 1 . When calculating the human labour, a driver + and an assistant have been assigned for tillage, disinfection, fertilizing and irrigation works, 10 people were assigned for harvesting and hoeing and only one person/driver has been assigned for other works including tractor.

Table 1. Energy balance in apple production

\begin{tabular}{|c|c|c|}
\hline Inputs & $\begin{array}{l}\text { Energy equivalence } \\
\left.\text { coefficient(MJ unit }{ }^{-1}\right)\end{array}$ & Resources \\
\hline Human Labour (h) & 1.96 & Karaağac et al., 2011; Mani et al., 2007 \\
\hline Machine Production Energy $(\mathrm{kg})$ & 64.80 & Kizilaslan, 2009; Singh, 2002 \\
\hline \multicolumn{3}{|l|}{ Fuel (L) } \\
\hline Diesel & 39.60 & Rathke and Diepenbrock, 2006 \\
\hline Oil & 6.51 & Sabah, 2010; Eren, 2011; Arıkan, 2011 \\
\hline \multicolumn{3}{|l|}{ Chemical Fertilizers (kg) } \\
\hline Nitrogen $(\mathrm{N})$ & 60.60 & Singh, 2002 \\
\hline Phosphor $\left(\mathrm{P}_{2} \mathrm{O}_{5}\right)$ & 11.10 & Singh, 2002 \\
\hline Potassium & 6.7 & Shrestha, 1998; Singh 2002 \\
\hline \multicolumn{3}{|l|}{ Disinfectant $(\mathrm{kg})$} \\
\hline Pesticides (kg) & 278 & $\begin{array}{l}\text { Yaldız et al., 1993; Dalgaard et al., 2001; } \\
\text { Yilmaz et al., } 2010\end{array}$ \\
\hline Fungicides $(\mathrm{kg})$ & 276 & Dalgaard et al., 2001; Y1lmaz et al., 2010 \\
\hline Electric $(\mathrm{kWh})$ & 3.60 & $1 \mathrm{kWh}=3.60 \mathrm{MJ}$ \\
\hline Irrigation water & 0.63 & Yaldız et al., 1993 \\
\hline \multicolumn{3}{|l|}{ Output } \\
\hline Fruit (kg) & 2.40 & Strapatsa et al., 2006 \\
\hline
\end{tabular}

\subsubsection{Time study and effective area work success}

For the duration measuring for determining the work successes $\left(\mathrm{ha} \mathrm{h}^{-1}\right)$ of agricultural procedures praticed throughout apple production duration, a watch has been used as a duration counter. Work success (Aiş) has been defined as effective area work success. When tillaging the study plots, effective work duration (Tef) has been determined as work productivity $\left(\right.$ ha $\left.^{-1}\right)$ (Güzel, 1986; Özcan, 1986). 


$$
\begin{aligned}
& \text { Aiş: } 0.10 * \mathrm{Bg} * \mathrm{Vg} * \text { Tef } \\
& \text { Tef: Tes / (Tes+Td+Tk) }
\end{aligned}
$$

\subsubsection{Determining fuel consumption}

The full tank method has been used when determining the fuel consumption by the tractor for each application in apple production. With this in mind, the fuel tank of the tractor has been filled fully before starting to work. At the end of the work, a scaled vessel has been used to re-fill the tank to the original level. Fuel amounts consumed for unit area has been defined by measuring the area and the amount of fuel filled (Göktürk, 1999; El Saleh, 2000; Sonmete, 2006).

\subsubsection{Fuel-oil energy input}

Fuel energy input and oil energy input have been calculated by the following formula (Gözübüyük et al., 2012).

\section{YKE: YT $x$ YKED \\ YĞE: (YT x 0.045) x YĞED}

In the equation;

YKE: Fuel energy input $\left(\mathrm{MJ} \mathrm{ha}^{-1}\right)$

\section{YĞE: Oil energy input (MJ/ha) \\ YT : Fuel consumption (1/ha) \\ YKED: Fuel's energy value $(\mathrm{MJ} / \mathrm{l})$ \\ YĞED: Oil's energy value (MJ/l)}

The calculations of human labour energy input, fertilizer energy input, chemicals energy input, input and irrigation energy input energy have been made by multiplying the energy equivalence of the input type and the input quantities consumed per unit area.

\subsubsection{Calculation of Energy Outputs}

Energy output yield per unit area has been calculated by the following formula (Öztürk, 2011).

$$
\text { TEÇ: (AÜVx Eaü )+(YÜVx Eyü) }
$$

In the equation;

TEÇ: Total energy output (MJ/ha), AÜV: Main product yield ( $\mathrm{kg} / \mathrm{ha})$, YÜV: Side product yield ( $\mathrm{kg} / \mathrm{ha})$,

Eaü: Energy equivalence of the main product $(\mathrm{MJ} / \mathrm{kg})$ Eyü: Energy equivalence of the side product $(\mathrm{MJ} / \mathrm{kg})$.

The indicators given in Table 2 have been availed of to define the energy efficiency (Eren, 2011).

Table 2. Energy efficiency indicators

Parameters Definition

\section{Energy rate}

Specific energy $\left(\mathrm{MJ} \mathrm{kg}^{-1}\right)$

Energy productivity $\left(\mathrm{kg} \mathrm{MJ}{ }^{-1}\right)$

Net Energy production $\left(\mathrm{MJ} \mathrm{ha}^{-1}\right)$

\section{Energy output / Energy input}

Total energy input / Total product amount harvested

Total product amount harvested / Total energy input

Total energy output - Total energy input

\section{Results and Discussion}

\subsection{Results}

The incoming and outgoing total energy values and energy efficiency indicators in apple production have been provided in Table3. Table 3 indicates that 7674.30 MJ ha ${ }^{-1}$ human energy has been consumed per unit area. In apple production, 5099.76 MJ energy has been consumed for 1 ha area in terms of machinery energy, and this value corresponded to a rate of $8.67 \%$ among the total energy value. Among all inputs, fertilizer energy input had the highest consumption level,17078.00 MJ ha', and rate, $29.02 \%$. Fuel-oil energy input, with a value of $14587.49 \mathrm{MJ} \mathrm{ha}^{-1}$, corresponded to $24.79 \%$. In apple production, chemicals energy input had a value of $12466 \mathrm{MJ} \mathrm{ha}^{-1}$ and a rate of $21.19 \%$, while irrigation energy input value was 1934.10 MJ $\mathrm{ha}^{-1}$ and the rate was $3.29 \%$.

As indicated in Table 3, the total energy input gained from apple production was 58839.65 MJ haand the total energy output was $92088 \mathrm{MJ} \mathrm{ha}^{-1}$.

Energy efficiency indicators in apple production have been provided in Table 4. According to Table 4, energy rate was 1.56 , specific energy was $1.53 \mathrm{MJ} \mathrm{kg}^{-1}$, energy production was $0.65 \mathrm{~kg} \mathrm{MJ}^{-1}$ and net energy was 33248.35 $\mathrm{MJ} \mathrm{ha}^{-1}$. 
Table 3. Energy balance in apple production

\begin{tabular}{|c|c|c|c|}
\hline Input & $\begin{array}{l}\text { Quantity per } \\
\text { hectare }\end{array}$ & $\begin{array}{l}\text { Total energy input } \\
\left(\mathrm{MJ} \mathrm{ha-}^{1}\right)\end{array}$ & $\begin{array}{c}\text { The rate of the inputs to total } \\
\text { energy Input }(\%)\end{array}$ \\
\hline Human labour (h) & 3915.46 & 7674.30 & 13.04 \\
\hline Soil preparation & 1.51 & 2.96 & \\
\hline Other procedures & 3247.28 & 6364.67 & \\
\hline Harvest & 666.67 & 1306.67 & \\
\hline Machine (h) & 78.70 & 5099.76 & 8.67 \\
\hline Tillage & 34.80 & 2255.04 & \\
\hline Other procedures & 43.90 & 2844.72 & \\
\hline Fuel + Oil (L) & 423.64 & 14587.49 & 24.79 \\
\hline Soil preparation & 88.83 & 3058.55 & \\
\hline Planting and other procedures & 334.82 & 11528.94 & \\
\hline Chemical Fertilizers (kg) & 500 & 17078 & 29.02 \\
\hline Phosphor (P) & 180 & 1998 & \\
\hline Nitrogen $(\mathrm{N})$ & 240 & 14544 & \\
\hline Potassium (K) & 80 & 536 & \\
\hline Chemicals (kg) & 45.00 & 12466 & 21.19 \\
\hline Insecticide & 23 & 6394 & \\
\hline Fungicide & 22 & 6072 & \\
\hline Irrigation $\left(\mathrm{m}^{3}\right)$ & 3070 & 1934.10 & 3.29 \\
\hline Total energy input $\left(\mathrm{MJ} \mathrm{ha}^{-1}\right)$ & & 58839.65 & 100.00 \\
\hline Direct energy input & & 22261.79 & 37.83 \\
\hline Indirect energy input & & 36577.86 & 62.17 \\
\hline Yield $\left(\mathrm{kg} \mathrm{ha}^{-1}\right)$ & 38370 & 92088 & \\
\hline Total energy output $\left(\mathrm{MJ} \mathrm{ha}^{-1}\right)$ & & 92088 & \\
\hline
\end{tabular}

Table 4. Energy efficiency indicators in apple production

\begin{tabular}{ll}
\hline Energy Rate & 1.56 \\
\hline Specific Energy $\left(\mathrm{MJ} \mathrm{kg}^{-1}\right)$ & 1.53 \\
\hline Energy Productivity $\left(\mathrm{kg} \mathrm{MJ}^{-1}\right)$ & 0.65 \\
\hline Net Energy Yield $(\mathrm{MJ})$ & 33248.35 \\
\hline
\end{tabular}

\section{Discussion}

The specific energy value of apple production under Tekirdağ conditions has been defined as $1.53 \mathrm{MJ} \mathrm{kg}^{-1}$. The energy rate in apple production has been defined as; 1.56 under Tekirdağ conditions, 1.63 under Isparta conditions (Ekinci et al., 2005), apple 2.26 under Antalya conditions (Y1lmaz et al., 2010) and 1.16 under Iran conditions (Rafiee et al., 2010). Energy production of apple cultivation under Tekirdağ conditions has been defined as $0.65 \mathrm{~kg} \mathrm{MJ}^{-1}$, when considering only the product yield per unit production area (ha).

Apple production under Tekirdağ conditions yields $0.65 \mathrm{~kg}$ of apple against $1 \mathrm{MJ}$ of energy consumption. This value for apple production has been reported as
$0.49 \mathrm{~kg} / \mathrm{MJ}$ in a study conducted under Tehran/Iran conditions by Rafiee et al. (2010). The difference between the total energy quantity gained at the end of production and the total energy quantity used in production processes is defined as net energy efficiency $\left(\mathrm{MJ} \mathrm{ha} \mathrm{h}^{-1}\right.$. Net energy in apple production under Tekirdağ conditions, when considering only the product yield per unit production area (ha), has been reported as $33248.35 \mathrm{MJ} \mathrm{ha}^{-1}$. In a study conducted in Antalya, the net energy efficiency in apple production has been reported as $67677.47 \mathrm{MJ}^{-1}$ ha by Yilmaz et al. (2010).

Following the calculations, it has been determined that among the production inputs, the highest share belonged to chemical fertilizer energy, which was respectively followed by fuel + oil, chemicals, machine, human labour and irrigation energy. In order to reduce fertilizer consumption, the choice of fertilizer should be made following the soil analysis results. Considering the energy output/input rate, it is possible to say that Tekirdağ apple production is quite productive.

\section{References}

Anonymous 2016a. Has fidancilik Elma, http://www.hasfidancilik.com.tr/index.php?option=com_c 
ontent\&view=article\&id=7\&Itemid=37 [Erişim tarihi: 28 Mart 2016]

Anonymous, 2016b. Türkiye'de elma üretimi, http://www.ulusaltarim.com/3508/Turkiye-de-elmaüretimi. [Erişim tarihi: 28 Mart 2016].

Anonymous 2016c. Tekirdağ coğrafi yapıs1, http://www.diyadinnet.com/YararliBilgiler-658\&Bilgi $=$ tekirda $\% \mathrm{C} 4 \% 9 \mathrm{~F} \% \mathrm{C} 4 \% \mathrm{~B} 1 \mathrm{n}-\mathrm{o} \% \mathrm{C} 4 \% 9$ Frafiyas $\% \mathrm{C} 4 \% \mathrm{~B} 1-$ ve-co\%C4\%9Frafi yap\%C4\%B1s\%C4\%B1 [Erişim tarihi: 28 Mart 2016].

Anonymous, 2016d. http://www.tarim.gov.tr/SGB/TARYAT/ Belgeler/il_yatirim_rehberleri/ tekirdag.pdf. [Erişim tarihi: 28 Mart 2016].

Arıkan, M., 2011. Adana ilinde kolza üretiminde enerji kullanımı. Yüksek Lisans Tezi, Çukurova Üniversitesi Fen Bilimleri Enstitüsü Tarım Makinaları Anabilim Dalı, Adana

Baran, M. F., Gökdoğan, O., 2014. Karpuz ve kavun yetiştiriciliğinde enerji girdi-çıktı analizi: Kırklareli ili örneği, Anadolu J. Agr Sci. 29(3): 217-224.

Baran, M. F., Gökdoğan, O., Karaağaç, H.A., 2014, Kanola üretiminde enerji kullanım etkinliğinin belirlenmesi (Kırklareli ili örneği), Türk Tarım ve Doğa Bilimleri Dergisi, Cilt:1(3): 331-337.

Baran, M. F., Gökdoğan, O., Bayhan, Y., 2015, Adıyaman ilinde organik nar yetiștiriciliğinde enerji kullanım etkinliğinin belirlenmesi, 29. Ulusal Tarımsal Mekanizasyon ve Enerji Kongresi, Cilt: 1, Sayfa : 502507, 02-5 Eylül 2015, Diyarbakır.

Cennet, O., Karaçayır, H. F., 2009. Türkiye'de elma üretimi, tüketimi, pazar yapısı ve dış ticareti, Tarım Bilimleri Araştırma Dergisi, 2(1): 41-49.

Dalgaard, T., Halberg, N., Porter, J.R., 2001. A model for fossil energy use in Danish agriculture used to compare organic and conventional farming. Agric Ecosyst Envi., 87: 51-65.

Ekinci, K., Akbolat, D., Demircan, V., Ekinci, Ç., 2005. Isparta ili elma üretiminde enerji kullanım etkinliğinin belirlenmesi, 3. Yenilenebilir Enerji Kaynakları Sempozyumu, Mersin.

El Saleh, Y., 2000. Suriye ve Türkiye'de mercimek ve nohut hasadında mekanizasyon olanaklarının belirlenmesi üzerine bir araştırma. Doktora Tezi. Çukurova Üniversitesi Fen Bilimleri Enstitüsü, Adana.

Eren, Ö., 2011. Çukurova Bölgesinde tatlı sorgum (sorghum bıcolor (1.) moench) üretiminde yaşam döngüsü enerji ve çevresel etki analizi. Doktora Tezi. Ç.Ü.Fen Bilimleri Enstitüsü Tarım Makinaları Ana Bilim Dalı.

Göktürk, B., 1999. Kuru soğanın hasada yönelik bazı özelliklerinin saptanması, kazıcı bıçaklı tip hasat makinesinin geliştirilmesi ve diğer hasat yöntemleri ile karşılaştırılması üzerine bir araştırma. Doktora Tezi. Trakya Üniversitesi Fen Bilimleri Enstitüsü, Tekirdağ.

Gözübüyük, Z., Demir, O., Öztürk, İ., Çelik, A., Zengin, H., Turgut, N., 2009. Erzurum kuru ve sulu tarım koşullarında değişik toprak işleme-ekim sistemlerinin, enerji ve işgücü gereksinimi, toprak ve nem muhafazası ile ürün verimi yönünden karşılaștırılması, Toprak ve $\mathrm{Su}$ Kaynakları Araştırma Enstitüsü Müdürlüğü, TAGEM-BBProje No: 980210K1.

Gözübüyük, Z., Çelik, A., Öztürk, İ., Demir, O., Adıgüzel, M.,C., 2012. Buğday üretiminde farklı, toprak işlemeekim sistemlerinin enerji kullanım etkinliği yönünden karşılaştırılması. Tarım Makineleri Bilimi Dergisi, 8(1): 25-34.

Güzel, E., 1986. Çukurova Bölgesinde yerfıstığının söküm ve harmanlanmasının mekanizasyonu ve bitkinin mekanizasyona yönelik özelliklerinin saptanması üzerine bir araştırma. Türkiye Zirai Donatım Kurumu Mesleki Yayınları, Yayın No: 47, Ankara.

Karaağac, H. A., S. Aykanat, B. Cakir, O. Eren, M. M. Turgut, Z. B. Barut, H. H. Ozturk., 2011. Energy balance of wheat and maize crops production in Haciali undertaking. 11th International Congress on Mechanization and Energy in Agriculture Congress, 21-23 September, Istanbul, Turkey, p. 388-391.

Kizilaslan, H., 2009. Input-output energy analysis of cherries production in Tokat province of Turkey. Applied Energy, 86: 1354-1358.

Mani, I., P. Kumar, J. S. Panwar, K. Kant., 2007. Variation in energy consumption in production of wheat-maize with varying altitudes in hill regions of Himachal Prades, India. Energy, 32: 2336-2339.

Özcan, M. T., 1986. Mercimek hasat ve harman yöntemlerinin iş verimi, kalitesi, enerji tüketimi ve maliyet yönünden karşılaştırılması ve uygun bir hasat makinası geliştirilmesi üzerine araştırmalar. Türkiye Zirai Donatım Kurumu Yayınları, Yayın No: 46. Ankara.

Öztürk, H. H., 2011. Bitkisel Üretimde Enerji Yönetimi. Hasad yayıncilik.

Pimentel D., 1980. Handbook of energy utilization in agriculture. Boca Raton, FL, CRC Pres.

Rafiee, S., Seyed, H., Mousavi, A., Ali M., 2010. Modeling and sensitivity analysis of energy inputs for apple production in Iran, Energy, 35: 3301-3306.

Rathke, G. W., Diepenbrock, W., 2006. Energy balance of winter oilseed rape (Brassica napus L.) cropping as related to nitrogen supply and preceding crop. Europ. J. Agronomy, 24: 35-44.

Sabah, M., 2010. Söke ovasında ikinci ürün yağlık ayçiçeği üretiminde enerji kullanımı. Yüksek Lisans Tezi. Çukurova Üniversitesi Fen Bilimleri Enstitüsü Tarım Makinaları Anabilim Dalı, Adana.

Shrestha, D.S., 1998. Energy use efficiency indicator for agriculture, Available from: http://www.usaskca/agriculture/caedac/PDF/mcrae.PDF,1 $0 / 10 / 2002$.

Singh, J. M., 2002. On farm energy use pattern in different cropping systems in Haryana, India. International Institute of Management University of Flensburg. Sustainable Energy Systems and Management. Master of Science, Germany.

Strapatsa, A.V., Nanos, G.D., Tsatsarelis, C.A., 2006. Energy flow for integrated apple production in Greece. Agric Ecosyst Environ, 116: 176-180.

Sonmete, M. H., 2006. Fasulyenin hasat-harman mekanizasyonu ve geliştirme olanakları. Doktora Tezi. Selçuk Üniversitesi Fen Bilimleri Enstitüsü (Yayımlanmamış), Konya.

Yaldı, O., Ozturk, H. H., Zeren, Y., Bascetincelik, A., 1993. Energy usage in production of field crops in Turkey. 5th international congress on mechanization and energy in agriculture, Kusadasi, Turkey. October, 11-14, 527-536.

Yılmaz, İ., Özalp, A., Aydoğmuş, F., 2010. Antalya ili bodur elma üretiminde enerji kullanım etkinliğinin belirlenmesi: Elmalı ilçesi örneği, Akdeniz Üniversitesi Ziraat Fakültesi Dergisi, 23(2): 93-97. 